\title{
Sugarcane stems as larval habitat for the stable fly (Stomoxys calcitrans) in sugarcane plantations ${ }^{1}$
}

\author{
Paulo H.D. Cançado ${ }^{2 *}$, Taciany Ferreira ${ }^{3}$ Eliane M. Piranda ${ }^{4}$ and Cleber O. Soares ${ }^{2,3}$ \\ ABSTRACT.- Cançado P.H.D., Ferreira T., Piranda E.M. \& Soares C.O. 2013. Sugarcane stems \\ as larval habitat for the stable fly (Stomoxys calcitrans) in sugarcane plantations. Pes- \\ quisa Veterinária Brasileira 33(6):741-744. Embrapa Gado de Corte, Av. Rádio Maia 830, \\ Zona Rural, Campo Grande, MS 79106-550, Brazil. E-mail: paulo.cancado@embrapa.br \\ Outbreaks of stable fly, Stomoxys calcitrans, cause losses for livestock producers located \\ near sugarcane mills in Brazil, especially in southern Mato Grosso do Sul. The sugarcane \\ mills are often pointed by local farmers as the primary source of these outbreaks; some \\ mills also joined the farmers in combating the flies. Brazilian beef cattle production has \\ great economic importance in similar level to bio-fuel production as ethanol. In this con- \\ text, the wide-ranging knowledge on the biology and ecology of the stable fly, including \\ larval habitats and their reproduction sites is extremely important for further development \\ of control programs. This paper aims to report the occurrence and development of S. calci- \\ trans larvae inside sugarcane stems in three municipalities of Mato Grosso do Sul. The su- \\ garcane stems give protection against bad weather conditions and insecticide application. \\ In this way, for sustainable sugarcane growth specific research concerning this situation \\ should be conducted.
}

INDEX TERMS: Stable fly, Stomoxys calcitrans, ectoparasite, cattle, biofuel, parasite ecology.

RESUMO.- [Colmos de cana-de-açúcar como habitat para o desenvolvimento de larvas de mosca-dos-estábulos (Stomoxys calcitrans) em plantações de cana-de-açúcar.] Surtos de mosca dos estábulos, Stomoxys calcitrans, vêm causando prejuízos em fazendas de pecuaria localizadas próximas as usinas de cana no Brasil, especialmente no sul do Mato Grosso do Sul. As usinas são frequentemente apontadas pelos pecuarístas locais, como a principal fonte desses surtos e algumas destas usinas também se uniram aos agricultores no combate a este parasita. No Brasil, a produção de gado de corte tem grande importância econômica em nível semelhante ao de bio-combustíveis como o etanol. Neste contexto, o conhecimento amplo sobre a bioecologia, incluindo os habitats das larvas e os seus

\footnotetext{
${ }^{1}$ Received on May 23, 2013.

Accepted for publication on June 10, 2013.

${ }^{2}$ Embrapa Gado de Corte, Avenida Rádio Maia 830, Zona Rural, Campo Grande, MS 79106-550, Brazil.*Corresponding author: paulo.cancado@ embrapa.br

${ }^{3}$ Programa de Pós Graduação em Ciência Animal, Faculdade de Medicina Veterinária e Zootecnia, Universidade Federal de Mato Grosso do Sul (UFMS), Cidade Universitária s/n., Campo Grande, MS 79070-900.

${ }^{4}$ Centro de Ciências Biológicas e da Saúde, Universidade Federal de Mato Grosso do Sul (UFMS), Cidade Universitária s/n, Cx. Postal 549, Campo Grande, MS 79070-900.
}

locais de reprodução, é extremamente importante para o desenvolvimento de programas de controle para a mosca dos estábulos. Este trabalho teve como objetivo registrar que larvas de $S$. calcitrans podem desenvolver dentro do colmo da cana. Larvas foram encontradas dentro de colmos de cana de açúcar em três oportunidades em diferentes cidades. 0 colmo da cana pode dar proteção para as larvas em condições climáticas desfavoráveis e aplicação de inseticidas. Desta forma, para o crescimento sustentável destas atividades, mais pesquisas específicas focadas nestas relações devem ser realizadas.

TERMOS DE INDEXAÇÃO: Mosca-dos-estábulos, Stomoxys calcitrans, ectoparasita, bovinos, biocombustível, bioecologia parasitária.

\section{INTRODUCTION}

The stable fly, Stomoxys calcitrans L. (Diptera: Muscidae), is a hematophagous parasite which attacks mainly horses and cattle, and can in specific situations parasitize other mammals, including humans; for cattle, there are losses ranging from 10 to $30 \%$ reduction in weight gain or even $50 \%$ reduction in milk production. The bite of the insect is very painful. Due to the intermittent feeding habit, this fly is also described as an important mechanical vector of se- 
veral diseases for cattle and horses (Guimarães et al. 2001, Grisi et al. 2002, Koller et al. 2009)

Outbreaks of the stable fly have been causing losses to livestock producers located near sugarcane mills in Brazil, especially at southern Mato Grosso do Sul. These mills are often pointed by local producers as the primary source of the outbreaks; some mills joined the farmers in combating this scourge. However, the real causes of outbreaks are not clearly known, and important aspects of the biology of $S$. calcitrans in this unique agro-ecological system must be investigated (Koller et al. 2009, Barros et al. 2010). In possession of such information it will be possible to develop effective control programs.

In other regions, like Africa, Australia, Costa Rica and the United States, some by-products of agriculture are known to be substrates for the development of stable fly larvae. Some of these products stand out, as crops from pineapples, vegetables, hay, peanuts and sugarcane. However, the problem occurs when these crop by-products are left accumulated in the field for its decomposition, or when they underwent wrong management (Foil \& Hogsette 1994). The obvious solution for the problem would be to adopt correct practices for handling these products; but sometimes the solution depends on technologies not yet known. Even the adoption of recommendations already available may come up against lack of interest or technical guidance. Therefore, the management practices for some agricultural crops must be reviewed to ensure that their products are removed from the field or have a more appropriate allocation. Moreover, it is necessary for such management practices with health purpose to bring benefits to the farmer and for the sugar industry, so that its implementation is feasible and occurs effectively by the various actors of the problem.

Specifically, in Brazil, the production of sugarcane is booming due to the great incentives offered for ethanol fuel. The number of plants and the area they occupy systematically grow, resulting in progressive increase of by-products generated. In the last six years, the sugarcane crop area in Brazil increased from around 150\% to 315\% in Mato Grosso do Sul (MS). The total sugarcane crop area in MS is close to 500,000 hectares and the production is around 35 millions of tons. Most of this growth occurs on pasture lands and their use is changing from cattle to sugarcane; but today pasture and sugarcane are mixed in the same area (Bugenstab et al. 2012).

At the same time, recent years have been characterized by unusual weather conditions, mainly in Central Brazil. In 2008 , outbreaks of $S$. calcitrans were described as arising in the State of São Paulo, due to the use of filter cake and vinasse which result from the processing of sugarcane and are used as fertilizers in the fields. In 2009, outbreaks were widely reported by media in the central and southeastern areas of Brazil near the sugarcane mills (Koller et al. 2009, Barros et al. 2010). However, it is not possible to determine with certainty the source of the problem, mainly due to lack of information on this new agro-ecological situation that now presents itself. The following years, 2010 to 2012, the outbreaks still occurred at different places but always in the surroundings of sugarcane mills. Considering that the investment policy to stimulate the growth of the biofuels industry must remain, with an increase in generation of by-products, potential problems can be expected to grow.

Application of insecticides to control S. calcitrans has variable results, high cost and produces undesirable environmental impact. Another alternative for fly control is the burning of by-products which can serve as a substrate for fly development; but this practice is gradually being reduced by law, and should definitely be banned in next two years. The use of traps for the adult fly is a measure of monitoring and control used in other countries; but its efficiency depends on the epidemiological and environmental conditions of each region as well as the size of the infested area, and should be tested before their large-scale application. Despite the potential success, even partial, of the measures above, the best contribution for solution of this problem seems to be identification and elimination of the breeding sites of the fly.

In this context, the wide-ranging knowledge on the bio-ecology, including larval habitats and reproduction sites, is extremely important for further development of control programs against the stable fly. This paper aims to report that $S$. calcitrans larvae can develop inside sugarcane stems.

\section{MATERIALS AND METHODS}

Areas studied and scientific field trips. We sampled four different sugarcane mills and the neighboring cattle ranches. Three mills are located in Mato Grosso do Sul (MS) and one is in Mato Grosso (MT) (Table 1). A total of 11 trips were conducted from May 2011 to September 2012.

The scientific trips were undertaken due to complaints of producers or requested help from sugarcane mills and farmer unions. Each trip was planned to identify larval habits and possible causes of those outbreaks.

Sampling and processing. Before we started to search larval habitats, interviews were performed with cattle producers and technicians from the sugarcane mills. With information about management procedures, we could start to search into some directions. We looked for stable fly adults and larvae at any place, where existed decomposing organic material and vegetable fibers together. We used active observation with amplifiers and some other gardening equipment such as shovel and machete to stir the material and seek larvae. When larvae were found, the material was collected in plastic boxes and taken to the veterinary entomology laboratory, where we let the larvae develop to adults. The collected larvae were maintained at a controlled temperature of $27 \pm 2^{\circ} \mathrm{C}$ and a relative humidity of $70 \pm 10 \%$. Larvae development was observed daily until pupation and adult emergence. The adults were identified according to Guimarães et al. (2001). All reproduction sites were registered with photographs.

Table 1. Municipalities of studied farms and Global Positioning System (GPS) locations and trips dates

\begin{tabular}{|c|c|c|}
\hline City/State & GPS & Dates \\
\hline Angélica/MS & $22^{\circ} 09^{\prime} \mathrm{S} / 53^{\circ} 47^{\prime} \mathrm{W}$ & $\begin{array}{l}\text { May, 2011; August, 2011; May, 2012; } \\
\text { August, 2012; September, } 2012\end{array}$ \\
\hline $\begin{array}{l}\text { Nova Alvorada do } \\
\text { Sul /MS }\end{array}$ & $21^{\circ} 27^{\prime} \mathrm{S} / 54^{\circ} 23^{\prime} \mathrm{W}$ & May, 2012; July, 2012; August, 2012 \\
\hline Maracajú/MS & $\begin{array}{l}21^{\circ} 43^{\prime} \mathrm{S} / 55^{\circ} 30^{\prime} \mathrm{W} \\
17^{\circ} 50^{\prime} \mathrm{S} / 53^{\circ} 17^{\prime} \mathrm{W}\end{array}$ & 012 \\
\hline
\end{tabular}




\section{RESULTS AND DISCUSSION}

Stable fly (Stomoxys calcitrans) larvae were found in a variety of substrates already known as larval habitats, including litter or chicken manure, silage and fodder straw, sugarcane straw, filter cake and cattle manure (Guimarães 1983, 1984, Guimarães et al. 2001, Marcondes 2001, Koller et al. 2009, Barros et al. 2010). Barros et al. (2010) described the outbreaks in Mato Grosso do Sul in 2009, and found larvae in very similar places. In other agricultural regions of the World, various substrates, such as fruits or grains which remain humid, have been described as sites for larval development (Kettle 1995). Broce et al. (2005) reported outbreaks in the United States, when they began to use hay rolls in cattle feedlots. In the State of São Paulo large quantities of larvae have been observed in areas where filter cake and vinasse (by-products resulted from alcohol and sugar production) were used as fertilizers. The sugarcane straw resulting from mechanical harvesting was also diagnosed as larval habitat, particularly when moistened by vinasse and applied as fertilizer (Oda \& Arantes 2009).

Twice during the interviews performed with different sugarcane mill technicians, they described sugarcane ste$\mathrm{ms}$ as a larval habitat; but research on reproductive aspects
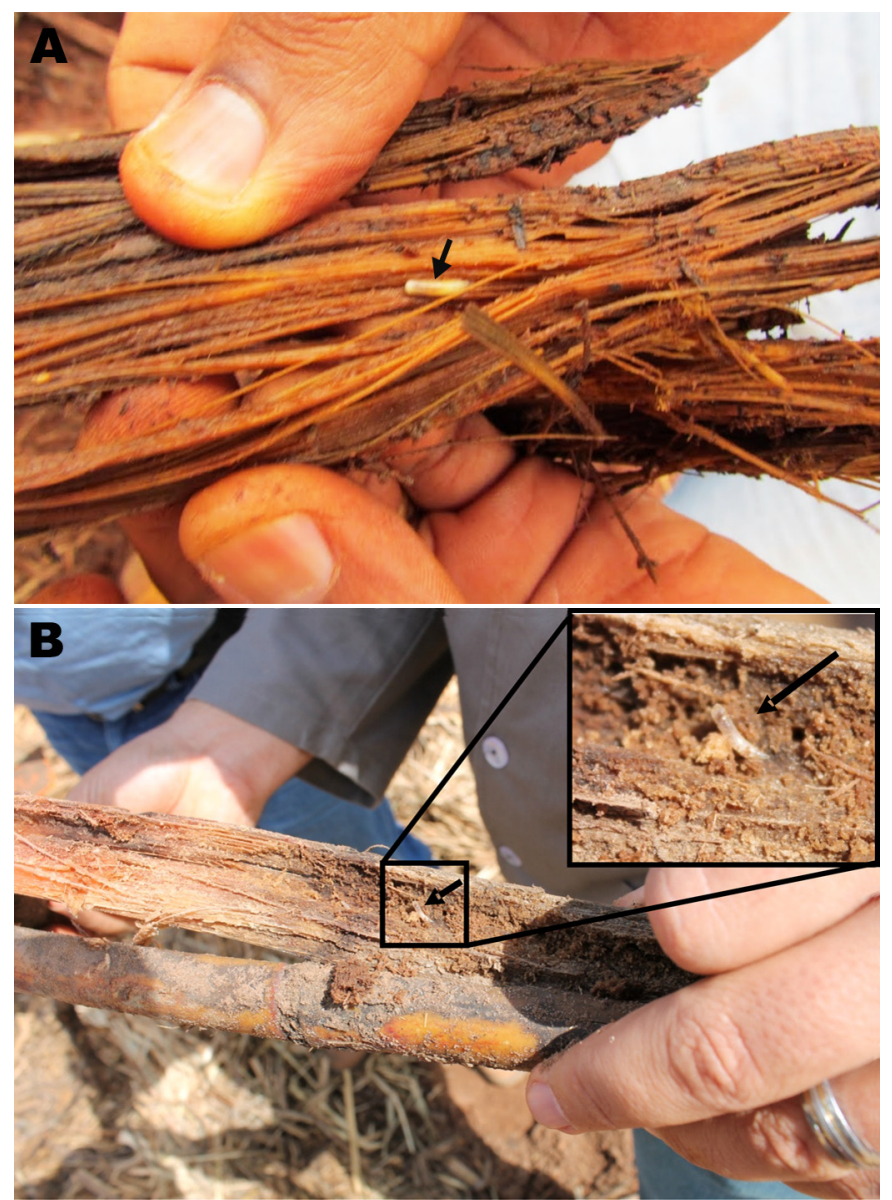

Fig.1. Decomposing sugarcane stems found in the field containing larvae of Stomoxys calcitrans inside. (A) Stem at an advanced stage of decomposition, arrow indicates larvae positions. (B) Stem in early stages of decomposition, box with the larva in an amplified view.

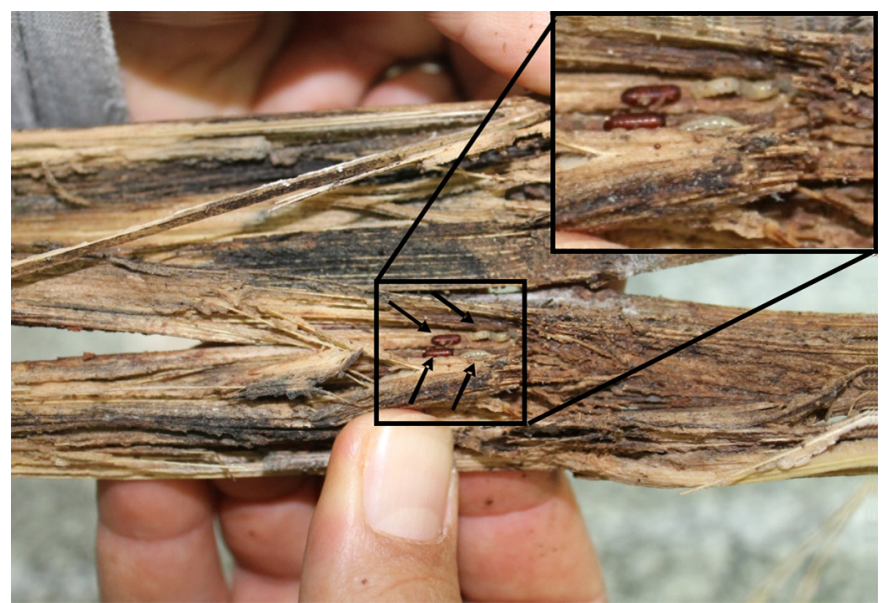

Fig.2. Sugarcane stems collected on the field, after three days under laboratory conditions, with larvae and developed pupae of Stomoxys calcitrans inside. Arrows indicates larvae and pupae positions; box with larvae and pupae in an amplified view.

did not mention the sugarcane stem as a possible larval habitat for S. calcitrans. After this information we started to look inside the sugarcane stems, and we found the larvae in three opportunities in different municipalities (Fig.1). It is important to notice that the stems were sliced and in decomposition after the sugarcane harvest. During the harvesting process some pieces of stems are left on field by the harvesting machine. Usually these stem pieces are 15$40 \mathrm{~cm}$ long and are mixed with the straw scattered over the ground. The stem pieces were taken to the laboratory and larval development was observed until pupation (Fig.2). Eleven days after collection, the adults emerged and we could identify them as S. calcitrans.

This newly found larval habitat is different from others described in Brazil, and there is nothing to control the larvae inside the sugarcane stem. It could be difficult to apply any kind of insecticide to reach the larvae in the stem. The sugarcane stem gives not only protection against chemical control, but also protection against bad weather conditions.

It is clear that climatic and environmental conditions are related to fluctuation of the stable fly population. In the years when outbreaks occurred there were unusual weather conditions, what probably contributed to the environmental imbalance and consequently to the occurrence of the outbreaks (Koller et al. 2009, Barros 2010). Apparently the development of fly is facilitated by the increase of precipitation in early spring (Guimarães 1984, Bittencourt 1998, Marcondes 2001); that is, when high humidity and temperature combine to give favorable conditions for the fly to find a substrate for oviposition and larval development, and outbreaks appear. Few studies on seasonality in Brazil were conducted only over short periods (about 1 year) (Rodriguez-Batista \& Leite 1997, Mari 2006, Zimmer et al. 2010). Thus, little information on the seasonality of $S$. calcitrans in Brazil is available. Some studies show consistent results demonstrating a positive correlation between temperature and humidity on the population increase of $S$. calcitrans, thereby indicating that a greater number of flies are found in spring and early summer. Subsequently, the 
population level remains elevated as long as the rainy season persists (Kasai et al. 1990, Bittencourt \& Borja 2000, Rodriguez-Batista et al. 2005).

At two opportunities we found these larvae inside sugarcane stems during the dry season (August 2012) without any rain for more than 50 days and with relative humidity lower than $35 \%$. Those stems possibly could be the only habitat for these larvae to survive in that dry environment. So, we can infer that these small pieces of sugarcane stems could be an important larval habitat for the stable fly population during the dry season, especially when after vinasse appliance the sugarcane straw is drying in shorter time than the larval period. We do not know if the flies are laying eggs directly upon the sugarcane surface or, more probably, they lay their eggs upon straw (after rain or vinasse appliance), and when these substrates become dry, the larvae migrate to inside the stem. The fact that the stable fly develops inside the stem shows that the parasite is adapting to the new environment created by sugarcane mills activities. This finding is extremely important and must be reported and additional research carried out because the critical situation farmers are going through. As the Brazilian beef cattle production has great economic importance, at a similar level as the ethanol production, specific research concerning the influences regarding both, cattle and ethanol industries, has to be performed for their sustainable growth.

\section{REFERENCES}

Barros A.T.M., Koller W.W., Catto J.B. \& Soares C.O. 2010. Surtos por Stomoxys calcitrans em gado de corte no Mato Grosso do Sul, Brasil. Pesq. Vet. Bras. 30:945-952.

Bittencourt A.J. \& Borja G.E.M. 2000. Stomoxys calcitrans (L.): preference for regions of the body feeding of horses. Parasitol. Día. 24:119-122.

Bittencourt A.J. 1998. Aspectos clínicos epidemiológicos de Stomoxys calcitrans (Linnaeus, 1758) em bovinos e cavalos em Espírito Santo do Pinhal, SP. Doutorado em Ciências Veterinárias, Universidade Federal Rural do Rio de Janeiro, Itaguaí, RJ. 120p.

Broce A.B., Hogsett J. \& Paisley S. 2005. Winter feeding sites of hay in round bales the major developmental sites of Stomoxys calcitrans (Diptera: Muscidae) in pastures in spring and summer. J. Econ. Entomol. 98:2307-2312.
Bungenstab D.J., Lopes C.H.L., Soares C.O., Saldanha E.P. \& Malafaia G.C. 2012. Agronegócio com Sustentabilidade - A Eficiência das Cadeias Produtivas em Mato Grosso do Sul. Embrapa, Brasília, DF. 72p.

Foil L.D. \& Hogsette J.A. 1994. Biology and control of tabanids, stable and horn flies. Rev. Sci. Tech. Off. Int. Épizoot. 13:1125-1158.

Grisi L., Massard C.L., Moya Borja G.E. \& Pereira J.B. 2002. Impacto econômico das principais ectoparasitoses em bovinos no Brasil. Hora Vet. 21:8-10.

Guimarães J.H. 1983. Flies: biology, ecology and control. Agrochemistry 21:20-26.

Guimarães J.H. 1984. Fly stables: an important pest of cattle. Agrochemistry 23:10-14.

Guimarães J.C., Tucci E.C. \& Barros-Batestti D.M. 2001. Ectoparasites of Veterinary Importance. Pleiade, São Paulo. 213p.

Kasai N., Schumaker T.T.S. \& Dell’Porto A. 1990. Variação sazonal de dípteros capturados em armadilha de Magoon modificada, em Santana de Paranaíba. Estado de São Paulo. Revta Bras. Entomol. 34:369-380.

Kettle D.S. 1995. Medical and Veterinary Entomology. CAB International, Wallingford. 725p.

Koller W.W., Catto J.B., Bianchini I., Soares C.O., Paiva F., Tavares L.E.R. \& Graciolli G. 2009. Outbreaks of the fly-stables, Stomoxys calcitrans, in Mato Grosso do Sul: new problem for the productive chains of flesh and sugarcane? Embrapa Gado de Corte, Campo Grande, MS. 31p.

Marcondes C.B. 2001. Entomologia Médica e Veterinária. Atheneu Editora, São Paulo. 432p.

Mari A.I. 2006. Utilização dos fungos Beauveria bassiana e Metarhizium anisopliae para o controle de muscídeos em estábulos na região de Blumenau, SC. Dissertação de Mestrado em Engenharia Ambiental, Centro de Ciências Tecnológicas, Universidade Regional de Blumenau, Blumenau, SC. 58p.

Oda F.H. \& Arantes A.C. 2009. Surge population of the stable fly Stomoxys calcitrans Linnaeus, 1758 (Diptera: Muscidae) in the district of Plateau, SP. Annals International Scientific Production, CESUMAR, Maringá, PR, p.27-30. (Artigo)

Rodríguez-Batista Z., Leite R.C., Oliveira P.R., Lopes C.M.L. \& Borges L.M.F. 2005. Populational dynamics of Stomoxys calcitrans Linneaus (Diptera: Muscidae) in three biocenoses, Minas Gerais, Brazil. Vet. Parasitol. 130:343-346.

Rodríguez-Batista Z. \& Leite R.C. 1997. Occurrence of biological vector of Dermatobia hominis (L. Jr, 1781) (Diptera: Cuterebridae), trapped in the region magoom metallurgical state of Minas Gerais, Brazil. Ciência Rural 27:645-649.

Zimmer C.R., Araújo D.F. \& Ribeiro P.B. 2010. Population fluctuations muscidae (Diptera, Muscidae) muscids and their distribution over the body of dairy cattle in Capon do Leão, RS, Brazil. Ciência Rural 40:604-610. 